\title{
Experiences and perception towards reproductive health education among secondary school teachers in South India
}

Nitin Joseph ${ }^{1 *} \mathbb{D}$, Vaibhav Mahato², Akhil Pandey², Shikha Mishra², Garima Prakash² and Rishika Gandhi

\begin{abstract}
Background: Reproductive health education (RHE) is an important component of school curricula. It helps students in the decision-making process regarding several issues concerning reproductive health. However delivering RHE at schools is a difficult task for the teachers.

Methods: This study was conducted to assess the experiences and perceptions towards reproductive health education (RHE) among 236 secondary school teachers in January 2019. Data were collected using a self-administered questionnaire.

Results: Only 21 (8.9\%) were trained in RHE. Majority [179 (75.8\%)] identified cultural barriers as the major challenge involved in its implementation. 95 (40.3\%) teachers felt that the provision of sexual education as a part of RHE will promote pre-marital sexual activity among the students. Of the total, 185 (78.4\%) had average while 51 (21.6\%) participants had a good perception towards RHE. It was taught in only $3(16.7 \%)$ out of the 18 schools surveyed. Only 11 (4.7\%) participants felt that the availability of teaching aids to conduct RHE classes at their schools was adequate. Hardly 14 (5.9\%) teachers had taken RHE classes for students. Among the rest, 135 (60.8\%) expressed their willingness to take RHE classes with appropriate training. In multi variable analysis, participants aged $\leq 40$ years $(p=0.031)$, those belonging to nuclear families ( $p=0.013)$, and those who had taken classes in RHE ( $p=0.037)$ had significantly good perception level towards RHE.
\end{abstract}

Conclusions: Teachers therefore need to be trained and given more opportunities to take RHE sessions which will help improve their perception towards RHE. Schools need to be better equipped with resources and various perceived barriers need to be overcome before RHE can be successfully implemented.

\section{Plain language summary}

This study was conducted to assess the experiences and perceptions towards reproductive health education (RHE) secondary school teachers. The participants provided the required information by filling a questionnaire. Hardly one in ten of them had prior training in RHE and one in twenty had taken RHE classes at schools. More than three-fourth of

\footnotetext{
*Correspondence: drnitinjoseph@gmail.com

${ }^{1}$ Department of Community Medicine, Kasturba Medical College,

Mangalore, Manipal Academy of Higher Education, Manipal, Karnataka, India

Full list of author information is available at the end of the article
}

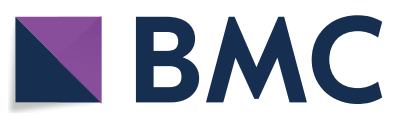

2021. Open Access This article is licensed under a Creative Commons Attribution 4.0 International License, which permits use, sharing, adaptation, distribution and reproduction in any medium or format, as long as you give appropriate credit to the original author(s) and the source, provide a link to the Creative Commons licence, and indicate if changes were made. The images or other third party material in this article are included in the article's Creative Commons licence, unless indicated otherwise in a credit line to the material. If material is not included in the article's Creative Commons licence and your intended use is not permitted by statutory regulation or exceeds the permitted use, you will need to obtain permission directly from the copyright holder. To view a copy of this licence, visit http://creativecommons.org/licenses/by/4.0/. The Creative Commons Public Domain Dedication waiver (http://creativeco mmons.org/publicdomain/zero/1.0/) applies to the data made available in this article, unless otherwise stated in a credit line to the data. 
them felt that cultural barriers could pose problems in its implementation at schools. One in four teachers had good perception towards RHE. Two in three among teachers, who had not taken RHE classes before, expressed their willingness to take RHE classes with appropriate training. Favourable perception towards RHE were expressed by teachers who were young, from small families and those who had taken RHE classes before.

Keywords: Experiences, Perception, Reproductive health education, Secondary school teachers, Urban area

\section{Introduction}

Reproductive health education (RHE) is an important component of school curricula. It helps students in the decision-making process regarding several issues concerning reproductive health $[1,2]$. The international community has always lent its support for the implementation of RHE at schools thereby protecting the rights of the adolescent population [3]. The importance of RHE has been acknowledged in the Sustainable Development Goals Agenda so as to ensure that the necessary knowledge and skills in this area are acquired by all learners. This would support the efforts aimed at ending all forms of violence against girls and women everywhere [4].

The scenario of its implementation in schools in developing countries like India has not been fully explored within academic literature. The Adolescence Education Program (AEP) in India was launched in 2005 to cover all secondary schools [5]. However, several political, religious leaders and teachers themselves opined that the AEP was against Indian cultural and moral values. Critics also felt that its introduction might encourage sexual activity among adolescent population. It was therefore banned across several states in India, including the state of Karnataka in 2007 [6-8].

The current state of RHE in schools across India appears to be in a disorganized manner. Most teachers do not teach RHE due to reasons such as embarrassment, or it not being part of the curriculum [9]. Studies have also observed that most parents are hesitant to discuss reproductive health-related issues with their children [10]. Moreover the information on these matters obtained from mass media and society, although easily accessible, are not always accurate and reliable.

Family, society and schools all have a responsibility in providing RHE to the adolescent population. Since teachers spend a considerable amount of time with the students, it is easier for them to implement RHE as a part of teaching activity. Hence, schools become an ideal and reliable setting to offer RHE for the young population [11]. For this to materialize, the teachers need to be first equipped with the necessary knowledge, skills and comfort level to effectively deliver RHE. For effective implementation of sessions on any sensitive topics such as RHE, the concerns and the expectations desired by teachers for teaching RHE in the classroom set-up, needs to be well understood.

This study was hence designed to study the experiences and perceptions towards RHE among secondary school teachers.

\section{Methods}

This cross-sectional study was conducted in Mangalore city situated on the western coast of South India in January 2019. The Institutional Ethics Committee granted ethical clearance. Adopting a simple random sampling technique, six secondary schools (8th to 10th standard) each from government, aided (institute owned by private management but receives aid from the government) and private schools situated within the city limits were chosen for this study.

The permission to conduct the study at the government and the aided schools was taken from the Block Education Officer (BEO) of Dakshina Kannada District. Further, permission to conduct the study at the school was taken from the respective school principals. Later the school teachers were approached and were informed of the nature and the purpose of the study. The school principals and teachers were assured complete anonymity of the information which were to be collected. Informed consent for participation was taken in writing from all the consenting teachers.

Based on the findings of a previous study done in Chandigarh, India [12] where $88 \%$ of school teachers were reported to have favorable perception towards RHE; the sample size using the formula $\mathrm{Z}_{\alpha}{ }^{2} \mathrm{pq} / \mathrm{d}^{2}$ at $95 \%$ confidence intervals, $5 \%$ relative precision and adding a nonresponse rate of $10 \%$, was calculated as 231 .

Teachers were approached in their waiting rooms at schools. They were enrolled using the convenience sampling method. Teachers with a minimum of one-year teaching experience and those consenting for participation were included in this study. Data were collected using a self-administered questionnaire. The questionnaire was content validated with the help of subject experts. In the government and aided schools, the Kannada version of the questionnaire was used. It was language validated by translation and back translation with the help of language experts. 
Pre-testing of the questionnaire was done based on the responses of 10 teachers chosen non-randomly from a private school which was not included in the main study. Cronbach's alpha value for the reliability of the questionnaire (after excluding the sociodemographic information of the teachers) was 0.88 .

The questionnaire was semi-structured with both open and closed-ended questions. The initial part of the questionnaire was designed to obtain sociodemographic information and details of prior training in RHE amongst the teachers. Section A consisted of questions assessing the views and opinions of teachers regarding RHE. This included various aspects like their perceptions on the necessity of RHE at schools, regarding topics to be covered under RHE, right class to introduce RHE, whether these classes need to be taken separately for boys and girls, need of permanent personnel at schools to teach RHE, barriers involved in teaching RHE at schools and likely problems if there were no RHE for school students. Additionally, teachers' perception towards a sensitive question, namely, whether the provision of sexual education as a part of RHE at the school level would promote early sexual activity among the learners, was also enquired under this section.

Section B focused on implementation of RHE at the surveyed schools. Teachers in this section were enquired about, the details of personnel taking RHE classes, the availability of teaching aids to conduct RHE and the adequacy of the content related to RHE taught at their schools.

Section $\mathrm{C}$ consisted of questions to teachers to enquire their experiences of teaching RHE, the comfort level experienced by them whilst teaching, incidents of any disruptive behavior by students during sessions and any report of objections by the parents for teaching RHE at schools. The various topics under RHE for which the teachers felt that they needed more training were also enquired. For those teachers who had not taken any RHE classes so far, their willingness to teach RHE, if the required training was offered to them, was enquired from them.

The questionnaires took approximately $20 \mathrm{~min}$ for each respondent to fill. The investigators were present at the venue to respond to any clarifications from the study participants during the data collection phase. Perception level towards RHE was assessed based on the responses to seven questions designed in a five-point Likert scale which comprised of five positively worded questions: whether teachers felt RHE is necessary for school students, should RHE be placed as a separate chapter in science textbooks, should RHE classes be taken separately for boys and girls, whether there is a need for permanent personnel to be employed at schools to exclusively deal with problems on reproductive health among students and whether they were willing to take classes on RHE with appropriate training. Five points were awarded for a "strongly agree", 4 for "agree", 3 for "neutral", 2 for "disagree" and 1 for "strongly disagree" response. In lieu of the last question, for those teachers who had already taken RHE classes earlier, 5 points meant for the "strongly agree" response, were awarded to each of them. For the other two questions which were negatively worded: whether RHE classes should be taken by same-gender teachers to the same-gender students and whether sexual education will promote early sexual activity among students, reverse scoring was done. The minimum attainable score based on the responses to these seven questions was 7 and the maximum was 35 .

Therefore, scores ranging from 7 to 16 were considered as poor, 17 to 26 as average and 27 to 35 as good perception level towards RHE among the teachers.

Data entry and analysis were done using International Business Machines Corporation (IBM) Statistical Package for the Social Sciences (SPSS) for Windows version 25.0, Armonk, New York. Fisher's exact test was used to test association. Chi-square test and Binary logistic regression analysis were also used to determine the variables associated with good perception towards RHE among school teachers. The $p<0.05$ was taken as the cutoff for statistical significance.

\section{Results}

A total of 257 teachers were eligible to take part in this study. However, only 236 (91.8\%) of them returned satisfactorily filled questionnaires.

The mean age of the teachers was $40.3 \pm 9.5$ years. (Table 1) Only $60(25.4 \%)$ taught science-related subjects while the rest taught other subjects. The mean years of teaching experience among the participants were $11.9 \pm 7.1$ years. The years of teaching experience ranged from 1 to 33 years. (Table 2).

Only $21(8.9 \%)$ teachers were trained in RHE. Overall, the training in RHE was observed to be inadequate among the participants. (Table 3).

As many as 215 (91.1\%) of the total participants agreed/ strongly agreed that there was a necessity for RHE for school students. Overall, the teachers had a favorable perception of RHE. (Table 4).

When the teachers were asked regarding who they felt were the right persons to teach RHE to the students, the majority [156 (66.1\%)] stated biology teachers. The other personnel identified by participants suitable for this task were student counsellors [88 (37.3\%)], obstetricians [83 $(35.2 \%)]$, any trained personnel [83 (35.2\%)], medical officers [66 (28\%)], teachers [47 (19.9\%)], pediatricians 
Table 1 Socio demographic distribution of school teachers $(n=236)$

\begin{tabular}{lcc}
\hline Characteristics & Number & Percentage \\
\hline Age (years) & 7 & \\
$\leq 25$ & 39 & 3.0 \\
$26-30$ & 37 & 16.5 \\
$31-35$ & 40 & 15.7 \\
$36-40$ & 46 & 16.9 \\
$41-45$ & 29 & 19.5 \\
$46-50$ & 14 & 12.3 \\
$51-55$ & 24 & 5.9 \\
$>55$ & & 10.2 \\
Gender & 88 & \\
Males & 148 & 37.3 \\
Females & & 62.7 \\
Type of family & 138 & \\
Nuclear & 98 & 58.5 \\
Joint & & 41.5 \\
Native place & 189 & 80.1 \\
Urban & 47 & 19.9 \\
Rural & 236 & 100.0 \\
Total & & \\
\hline
\end{tabular}

Table 2 Distribution of teachers based upon school related characteristics $(n=236)$

\begin{tabular}{lcc}
\hline Characteristics & Number & Percentage \\
\hline Type of school (based on ownership) & & \\
Government & 80 & 33.9 \\
Aided & 81 & 34.3 \\
Private & 75 & 31.8 \\
Type of school (based on co-education status) & & \\
Co-educational school & 227 & 96.2 \\
All-boys school & 3 & 1.3 \\
All-girls school & 6 & 2.5 \\
Educational background & & \\
Science & 93 & 39.4 \\
Arts & 143 & 60.6 \\
Subjects taught at school & & \\
Science related & 60 & 25.4 \\
Others & 176 & 74.6 \\
Teaching experience (years) & & \\
1-5 & 53 & 22.5 \\
$6-10$ & 71 & 30.1 \\
$11-15$ & 46 & 19.5 \\
$16-20$ & 35 & 14.8 \\
$21-25$ & 21 & 8.9 \\
$>25$ & 10 & 4.2 \\
Total & 236 & 100.0 \\
\hline
\end{tabular}

[41 (17.4\%)], parents [38 (16.1\%)], class teachers [29 (12.3\%)], senior teachers [10 (4.2\%)] and school principals [10 (4.2\%)]. Reasons for these preferences were: due to their proficiency in knowledge regarding reproductive health [223 (94.5\%)], their accessibility [32 (13.6\%)] and familiarity [25 (10.6\%)] with the students, as stated by the participants.

The common topics under RHE to be covered at schools as opined by the participants were concepts of puberty [209 (88.6\%)], awareness of good/bad touch [177 $(75 \%)]$, menstrual hygiene [174 (73.7\%)], information on sexually transmitted diseases (STDs) [159 (67.4\%)], description and functions of reproductive organs [143 (60.6\%)], benefits of ideal family size [140 (59.3\%)], information about right age at marriage [139 (58.9\%)], concept of menarche [136 (57.6\%)], information about right age at pregnancy [134 (56.8\%)], sexual abuse/harassment [133 (56.4\%)] and about contraceptives [38 (16.1\%)].

Topics under RHE which the participants specifically suggested to be introduced before secondary school were: awareness of good/bad touch [55 (23.3\%)], about concepts of puberty [20 (8.5\%)], description and functions of reproductive organs [13 (5.5\%)] and menstrual hygiene [6 (2.5\%)].

Topics under RHE which the participants specifically suggested to be introduced after secondary school were: issues concerning teenage pregnancies [48 (20.3\%)], about contraceptives [33 (14\%)], information on STDs [5 (2.1\%)] and description and functions of reproductive organs [5 (2.1\%)].

The common challenges involved in teaching RHE in schools as opined by teachers were: cultural barriers [179 (75.8\%)], parental objections [94 (39.8\%)], lack of a standardized teaching module [61 (25.8\%)], teachers not being trained in RHE [52 (22\%)], school administrators not recognizing the importance of RHE [15 (6.4\%)] and unavailability of sufficient resource materials at schools to conduct RHE sessions [ (11 (4.7\%)].

The common problems that would be encountered if there were no RHE at schools as perceived by the participants were: students ending up acquiring incorrect information about reproductive health from various informal sources [109 (46.2\%)], students ending up in an anxious state when they encounter issues concerning reproductive health [102 (43.2\%)], greater risk of teenage pregnancies [45 (19.1\%)], more chances of premarital sexual experiences [39 (16.5\%)], more instances of abortions [16 (6.8\%)] and risk of having an unsuccessful marital life in future $[15(6.4 \%)]$.

Out of the 215 teachers who agreed/strongly agreed with the introduction of RHE in schools, 76 (35.3\%) felt that it would help students to understand more about themselves and $29(13.5 \%)$ felt that it would 
Table 3 Characteristics related to reproductive health education (RHE) training among school teachers

\begin{tabular}{|c|c|c|}
\hline Characteristics & Number & Percentage \\
\hline \multicolumn{3}{|l|}{ Trained in RHE $(n=236)$} \\
\hline Yes & 21 & 8.9 \\
\hline No & 215 & 91.1 \\
\hline \multicolumn{3}{|c|}{ Number of training sessions attended $(n=21)$} \\
\hline 1 & 8 & 38.1 \\
\hline 2 & 10 & 47.6 \\
\hline 3 & 3 & 14.3 \\
\hline \multicolumn{3}{|c|}{ The time gap between the most recent training session with the present time $(n=21)$} \\
\hline$\leq 2$ years & 4 & 19.1 \\
\hline $2.1-3$ years & 5 & 23.8 \\
\hline $3.1-5$ years & 3 & 14.2 \\
\hline $5.1-10$ years & 4 & 19.1 \\
\hline$>10$ years & 5 & 23.8 \\
\hline \multicolumn{3}{|c|}{ Personnel who conducted the most recent training $(n=21)$} \\
\hline Medical professionals & 15 & 71.4 \\
\hline Teachers & 6 & 28.6 \\
\hline \multicolumn{3}{|c|}{ The venue of training $(n=21)$} \\
\hline At the school & 21 & 100.0 \\
\hline \multicolumn{3}{|l|}{ Certified training $(n=21)$} \\
\hline Yes & 2 & 9.5 \\
\hline No & 19 & 90.5 \\
\hline \multicolumn{3}{|c|}{ Other sources of information about RHE $(n=236)^{\dagger}$} \\
\hline Textbooks & 183 & 77.5 \\
\hline Internet & 141 & 59.7 \\
\hline Television & 137 & 58.0 \\
\hline Colleagues & 119 & 50.4 \\
\hline
\end{tabular}

${ }^{\dagger}$ Multiple responses

benefit students in getting all their misconceptions cleared regarding this topic. Among the 14 teachers who felt that RHE is to be introduced only for the girls, 6 (42.9\%) thought so because, girls in particular need to be aware of consequences following sexual misadventures.

The cumulative perception scores of the participants ranged from 17 to 30 . Among them, 185 (78.4\%) had average while 51 (21.6\%) had a good perception towards RHE.

Implementation of RHE at schools was done in only 3 (16.7\%) out of the 18 schools. Implementation of RHE was observed in a government, aided and private school. All these were co-educational schools. Formal RHE classes were given only in the private school and it was for students from 6 to 10th standard. Sessions were taken by both, teachers from the same institute and by teachers from other institutes. In the other two schools, RHE sessions were offered informally for only $10^{\text {th }}$ standard students and the resource persons were teachers from the same institution.
A total of 14 (5.9\%) teachers had taken classes on RHE. Overall, the majority of the participants felt that the resource materials for conducting RHE classes at the surveyed schools were not adequate. (Table 5).

Out of the 21 teachers who underwent training in RHE in the past, 3 (14.3\%) had taken classes on RHE for the students. Among the 215 teachers who did not undergo any form of training in RHE, 11 (5.1\%) had taken classes on RHE for the students $(p=0.116)$. This also infers that, out of the 14 teachers who had taken classes in RHE, 11 (78.6\%) did not undergo any form of training in RHE in the past.

Some of the open suggestions/observations given by teachers regarding reproductive health were: school students often find it uncomfortable in accepting their bodily changes during puberty (5), the current teaching of RHE at schools is inadequate (3), provision of sexual education as a part of RHE may promote premarital sexual activity among the students (3), the mass media have promoted obscenity leading to promiscuous behavior among the students (1) and that there are 
Table 4 Perception regarding reproductive health education among school teachers

\begin{tabular}{|c|c|c|}
\hline Characteristics & Number & Percentage \\
\hline \multicolumn{3}{|l|}{ The necessity of RHE for school students } \\
\hline Strongly agree & 67 & 28.4 \\
\hline Agree & 148 & 62.7 \\
\hline Neutral & 14 & 5.9 \\
\hline Disagree/strongly disagree & 7 & 3.0 \\
\hline \multicolumn{3}{|c|}{ When should it be introduced for school children $(n=215)$} \\
\hline 1st to 5 th standard & 23 & 10.7 \\
\hline 6th to 7 th standard & 88 & 40.9 \\
\hline 8th to 10 th standard & 104 & 48.4 \\
\hline \multicolumn{3}{|c|}{ When should it be introduced if not during schooling years $(n=7)$} \\
\hline During pre-university course & 6 & 85.7 \\
\hline Before marriage & 1 & 14.3 \\
\hline \multicolumn{3}{|l|}{ RHE should be introduced to which gender } \\
\hline Both boys and girls & 222 & 94.1 \\
\hline Only girls & 14 & 5.9 \\
\hline \multicolumn{3}{|c|}{ Should RHE sessions be taken separately for boys and girls } \\
\hline Strongly agree & 82 & 34.8 \\
\hline Agree & 92 & 39.0 \\
\hline Neutral & 14 & 5.9 \\
\hline Disagree & 42 & 17.8 \\
\hline Strongly disagree & 6 & 2.5 \\
\hline \multicolumn{3}{|c|}{ The same gender teacher should teach RHE to the same gender students } \\
\hline Strongly agree & 13 & 5.5 \\
\hline Agree & 65 & 27.5 \\
\hline Neutral & 70 & 29.7 \\
\hline Disagree & 73 & 30.9 \\
\hline Strongly disagree & 15 & 6.4 \\
\hline \multicolumn{3}{|c|}{ Suitable teaching aids to conduct RHE at schools ${ }^{\dagger}$} \\
\hline Posters & 130 & 55.1 \\
\hline Flip charts & 112 & 47.5 \\
\hline Video films & 91 & 38.6 \\
\hline Models & 66 & 28.0 \\
\hline \multicolumn{3}{|c|}{ RHE should be a separate chapter in science textbooks } \\
\hline Strongly agree & 48 & 20.3 \\
\hline Agree & 108 & 45.8 \\
\hline Neutral & 48 & 20.3 \\
\hline Disagree & 31 & 13.2 \\
\hline Strongly disagree & 1 & 0.4 \\
\hline \multicolumn{3}{|c|}{ RHE classes to be taught after usual teaching hours at schools } \\
\hline Yes & 29 & 12.3 \\
\hline No & 142 & 60.2 \\
\hline Not sure & 65 & 27.5 \\
\hline \multicolumn{3}{|c|}{ Should curriculum makers take teacher's suggestions while preparing a RHE module } \\
\hline Yes & 230 & 97.5 \\
\hline No & 6 & 2.5 \\
\hline \multicolumn{3}{|l|}{ Reasons for the same $(n=230)$} \\
\hline Teachers directly deal with students & 69 & 30.0 \\
\hline Teachers understand students the best & 7 & 3.0 \\
\hline
\end{tabular}


Table 4 (continued)

\begin{tabular}{|c|c|c|}
\hline Characteristics & Number & Percentage \\
\hline \multicolumn{3}{|c|}{ Need for permanent personnel at schools to exclusively deal with reproductive health-related problems among students } \\
\hline Strongly agree & 15 & 6.4 \\
\hline Agree & 106 & 44.9 \\
\hline Neutral & 98 & 41.5 \\
\hline Disagree & 12 & 5.1 \\
\hline Strongly disagree & 5 & 2.1 \\
\hline \multicolumn{3}{|c|}{ Provision of sexual education as a part of RHE will promote premarital sexual activity among the students } \\
\hline Strongly agree & 7 & 3.0 \\
\hline Agree & 88 & 37.3 \\
\hline Neutral & 72 & 30.5 \\
\hline Disagree & 67 & 28.4 \\
\hline Strongly disagree & 2 & 0.8 \\
\hline Total & 236 & 100.0 \\
\hline
\end{tabular}

${ }^{\dagger}$ Multiple responses

several misconceptions present regarding menstruation among girls (1).

Participants aged $\leq 40$ years, females, those belonging to nuclear families, those who underwent training in RHE and those who had taken classes in RHE, had significantly good perception level towards RHE as compared to the rest (Table 6).

In multivariable analysis, participants aged $\leq 40$ years $(p=0.031)$, those belonging to nuclear families $(p=0.013)$ and those who had taken classes in RHE $(p=0.037)$, had significantly good perception level towards RHE as compared to others (Table 7).

\section{Discussion}

The proportion of teachers who underwent training in RHE was only $8.9 \%$ in the present study in comparison to $25.8-70 \%$ reported in previous studies $[2,3,13,14]$. Considering the multidisciplinary nature of RHE, all teachers during their preservice and in-service training years need to be given training in reproductive health.

Close to three-fourth of teachers in the present study felt that RHE sessions need to be taken separately for boys and girls. In co-education RHE sessions, students might experience discomfort as learners of one gender may feel embarrassed to discuss with their teachers, certain topics under reproductive health, in the presence of students of the opposite gender.

More than three-fourth of teachers in this study felt that the cultural barriers were the main challenges involved in teaching RHE at schools. In previous studies, teachers listed religion, culture, restrictive policies, inadequate time being allotted, untrained teachers, lack of confidence among teachers, lack of infrastructure, lack of teaching aids, lack of support from teachers, objections raised by students, parents or school administrators, as the potential barriers for the same [2,14-20].

A total of $40.3 \%$ teachers in this study and $39-71.7 \%$ in previous studies felt that sex education as a part of RHE would promote early sexual activity among the students $[2,3,21]$. These misconceptions need to be addressed in training sessions for teachers in order to bring a more favorable perception towards RHE.

Implementation of RHE was seen merely among three of the surveyed schools in the present study. Moreover, just one out of these three schools had sessions taken by teachers from other institutions. In the South African study, it was observed that outside personnel like the Department of Health Officials and school nurses were occasionally invited to take RHE classes for the students [14]. Teachers at these schools felt that this initiative made RHE classes more effective because learners could relate and discuss sensitive issues concerning reproductive health better with outsiders than with their educators [14].

In this study, approximately $8 \%$ of respondents felt that the content of RHE sessions and approximately $5 \%$ felt that the teaching aids to conduct these sessions were adequate at their schools. Similarly, in the South African study, hardly $10 \%$ of teachers felt that the schools had adequate resources to enable them to take RHE classes [14].

In this study, approximately $6 \%$ of teachers had taken classes in RHE. Among them, most were not even trained in RHE. This dismal picture was also reported in a study done in four countries of pacific islands where a significant number of teachers taught RHE without any training [2]. Prior research has shown that training has a major 
Table 5 Experiences of teachers with reproductive health education sessions at the surveyed schools

\begin{tabular}{|c|c|c|}
\hline Characteristics & Number & Percentage \\
\hline \multicolumn{3}{|c|}{ Content of RHE delivered at the school } \\
\hline Adequate & 18 & 7.6 \\
\hline Inadequate & 88 & 37.3 \\
\hline Not sure & 130 & 55.1 \\
\hline \multicolumn{3}{|c|}{ Availability of teaching aids at schools to conduct RHE } \\
\hline Adequate & 11 & 4.7 \\
\hline Inadequate & 90 & 38.1 \\
\hline Not sure & 135 & 57.2 \\
\hline \multicolumn{3}{|l|}{ Taken classes on RHE } \\
\hline Yes & 14 & 5.9 \\
\hline No & 222 & 94.1 \\
\hline \multicolumn{3}{|c|}{ If not, willingness to take with appropriate training $(n=222)$} \\
\hline Agree & 135 & 60.8 \\
\hline Neutral & 54 & 24.3 \\
\hline Disagree & 12 & 5.4 \\
\hline Strongly disagree & 21 & 9.5 \\
\hline \multicolumn{3}{|c|}{ Topics under RHE for which additional training is required ${ }^{\dagger}$} \\
\hline Sexually transmitted diseases & 56 & 23.7 \\
\hline $\begin{array}{l}\text { Counselling children with issues } \\
\text { related to RHE }\end{array}$ & 53 & 22.5 \\
\hline Physiology of menstruation & 21 & 8.9 \\
\hline \multicolumn{3}{|c|}{ Feeling of uneasiness while taking classes on RHE $(n=14)$} \\
\hline Neutral & 1 & 7.1 \\
\hline Disagree & 7 & 50.0 \\
\hline Strongly disagree & 6 & 42.9 \\
\hline \multicolumn{3}{|c|}{$\begin{array}{l}\text { Feeling of uneasiness while taking classes on RHE to students of the } \\
\text { opposite gender }(n=14)\end{array}$} \\
\hline Neutral & 3 & 21.4 \\
\hline Disagree & 7 & 50.0 \\
\hline Strongly disagree & 4 & 28.6 \\
\hline \multicolumn{3}{|c|}{ Disruptive behaviour by students during RHE sessions $(n=14)$} \\
\hline Yes & 2 & 14.3 \\
\hline No & 12 & 85.7 \\
\hline \multicolumn{3}{|c|}{ Parental objection for taking classes on RHE $(n=14)$} \\
\hline Yes & 4 & 28.6 \\
\hline No & 10 & 71.4 \\
\hline Total & 236 & 100.0 \\
\hline
\end{tabular}

${ }^{\dagger}$ Multiple responses

influence on the confidence levels of teachers teaching sensitive topics like RHE. Lack of the required training was found to negatively impact their quality of teaching $[18,19]$.

Among the teachers who had taken RHE classes for students in this study, more than one-fourth of them reported parental objection to the conduct of these classes. In the South African study, 90\% of teachers
Table 6 Association between determinants and perception level towards reproductive health education among school teachers

\begin{tabular}{|c|c|c|c|}
\hline \multirow[t]{2}{*}{ Characteristics } & \multicolumn{2}{|c|}{ Perception level towards RHE } & \multirow[t]{2}{*}{ Total } \\
\hline & Good no. (\%) & Average no. (\%) & \\
\hline \multicolumn{4}{|l|}{ Age group } \\
\hline$\leq 40$ years & $36(29.3)$ & $87(70.7)$ & 123 \\
\hline \multirow[t]{2}{*}{$>40$ years } & $15(13.3)$ & $98(86.7)$ & 113 \\
\hline & & & $X^{2}=8.893, p=0.003$ \\
\hline \multicolumn{4}{|l|}{ Gender } \\
\hline Male & $12(13.6)$ & $76(86.4)$ & 88 \\
\hline \multirow[t]{2}{*}{ Female } & $39(26.4)$ & $109(73.6)$ & 148 \\
\hline & & & $X^{2}=5.267, p=0.022$ \\
\hline \multicolumn{4}{|l|}{ Type of family } \\
\hline Nuclear & $40(29)$ & $98(71)$ & 138 \\
\hline \multirow[t]{2}{*}{ Joint } & $11(11.2)$ & $87(88.8)$ & 98 \\
\hline & & & $\begin{array}{c}X^{2}=10.671 \\
p=0.001\end{array}$ \\
\hline \multicolumn{4}{|c|}{ Underwent training in RHE } \\
\hline Yes & $9(42.9)$ & $12(57.1)$ & 21 \\
\hline \multirow[t]{2}{*}{ No } & $42(19.5)$ & $173(80.5)$ & 215 \\
\hline & & & $X^{2}=6.143 p=0.013$ \\
\hline \multicolumn{4}{|c|}{ Taken classes on RHE } \\
\hline Yes & $8(57.1)$ & $6(42.9)$ & 14 \\
\hline \multirow[t]{2}{*}{ No } & $43(19.4)$ & $179(80.6)$ & 222 \\
\hline & & & $\begin{array}{c}X^{2}=11.092 \\
p=0.001\end{array}$ \\
\hline Total & 51 & 185 & 236 \\
\hline
\end{tabular}

reported a lack of support from parents [14]. Parental counseling on the importance of RHE might help in addressing these issues before initiating RHE sessions at schools.

Certain variables were found to be associated with good perception level towards RHE among participants in this study. In other studies, teachers with more than four years of teaching experience [22], science teachers [22], the gender of the teacher [23], trained teachers [23] and teachers teaching RHE [23] had a more positive attitude towards the importance of sex education at schools.

\section{Conclusions}

It is evident from the findings of this study that few teachers were trained in RHE. Similarly, few teachers had taken classes on RHE. Teachers therefore need to be trained during the pre and in-service training programs and need to be given more opportunities to take RHE sessions. This would benefit them in having a good perception of RHE, as supported by the observations of this 
Table 7 Binary logistic regression analysis of variables associated with good perception level towards reproductive health education among the school teachers $(n=236)$

\begin{tabular}{|c|c|c|c|c|c|c|c|c|}
\hline \multirow[t]{2}{*}{ Characteristics } & \multirow[t]{2}{*}{ Unadjusted OR } & \multicolumn{2}{|c|}{$\begin{array}{l}\text { 95\% } \mathrm{Cl} \text { for unadjusted } \\
\text { OR }\end{array}$} & \multirow[t]{2}{*}{$p$ value } & \multirow[t]{2}{*}{ Adjusted OR } & \multicolumn{2}{|c|}{$95 \% \mathrm{Cl}$ for adjusted OR } & \multirow[t]{2}{*}{$p$ value } \\
\hline & & Lower & Upper & & & Lower & Upper & \\
\hline \multicolumn{9}{|l|}{ Age (years) } \\
\hline$\leq 40$ & 2.703 & 1.386 & 5.272 & 0.003 & 2.147 & 1.073 & 4.299 & 0.031 \\
\hline$>40$ & 1 & & & & 1 & & & \\
\hline \multicolumn{9}{|l|}{ Gender } \\
\hline Males & 1 & & & & 1 & & & \\
\hline Females & 2.266 & 1.114 & 4.61 & 0.022 & 1.014 & 0.429 & 2.396 & 0.975 \\
\hline \multicolumn{9}{|l|}{ Type of family } \\
\hline Nuclear & 3.228 & 1.56 & 6.679 & 0.001 & 2.579 & 1.219 & 5.459 & 0.013 \\
\hline Joint & 1 & & & & 1 & & & \\
\hline \multicolumn{9}{|c|}{ Underwent training in $\mathrm{RHE}$} \\
\hline Yes & 3.089 & 1.222 & 7.812 & 0.013 & 2.163 & 0.813 & 5.751 & 0.122 \\
\hline No & 1 & & & & 1 & & & \\
\hline \multicolumn{9}{|c|}{ Taken classes in RHE } \\
\hline Yes & 5.55 & 1.83 & 16.835 & 0.001 & 3.4 & 1.08 & 10.709 & 0.037 \\
\hline No & 1 & & & & 1 & & & \\
\hline
\end{tabular}

study. Schools need to be better equipped with resources for the successful implementation of RHE.

\section{Limitations}

There is a possibility of under reporting of information on this sensitive topic by participants of this study.

\section{Abbreviations}

RHE: Reproductive health education; AEP: Adolescence Education Program; BEO: Block Education Officer; IBM: International Business Machines Corporation; SPSS: Statistical Package for the Social Sciences; STDs: Sexually transmitted diseases; Cl: Confidence interval; OR: Odds Ratio.

\section{Supplementary Information}

The online version contains supplementary material available at https://doi. org/10.1186/s12978-021-01224-6.

Additional file 1. Raw data of the research study.

\section{Acknowledgements}

We authors of this study thank the BEO of Dakshina Kannada District, Karnataka state for permitting us to do the study at the various Government and Aided schools at the setting. We also thank the Principals of the respective schools for granting us the permission. Finally, we thank all the teachers who enthusiastically took part in this study.

\section{Authors' contributions}

NJ: guarantor of this research work, concept, design, literature search, proforma preparation, data collection, data entry, data analysis, manuscript preparation, revising the work critically for important intellectual content. VM: literature search, manuscript preparation, interpretation of data, revising the work critically for important intellectual content, manuscript editing. AP: data entry, interpretation of data, revising the work critically for important intellectual content, manuscript editing. SM: literature search, interpretation of data, revising the work critically for important intellectual content, manuscript editing. GP: interpretation of data, revising the work critically for important intellectual content, manuscript editing. RG: interpretation of data, revising the work critically for important intellectual content, manuscript editing. All authors read and approved the final manuscript.

\section{Funding}

No funding was acquired for this study.

\section{Availability of data and materials}

The SPSS spread sheet containing the data of this research study has been uploaded as an Additional file 1.

\section{Declarations}

Ethics approval and consent to participate

The study protocol was approved by the Institutional Ethics Committee. The ethics approval number was IECKMCMLR/012/2019 on 14 ${ }^{\text {th }}$ January 2019.

\section{Consent for publication}

This was taken from the co-investigators of this study.

\section{Competing interests}

The authors declare that they have no competing interests.

\section{Author details}

${ }^{1}$ Department of Community Medicine, Kasturba Medical College, Mangalore, Manipal Academy of Higher Education, Manipal, Karnataka, India. ${ }^{2}$ Kasturba Medical College, Mangalore, Manipal Academy of Higher Education, Manipal, Karnataka, India.

Received: 22 June 2021 Accepted: 14 August 2021

Published online: 26 August 2021

\section{References}

1. Breuner CC, Mattson G. AAP Committee on Adolescence, AAP Committee on Psychosocial Aspects of Child and Family Health. Sexuality education for children and adolescents. Pediatrics. 2016;138:e20161348. 
2. United Nations Educational Scientific and Cultural Organization. Attitudinal survey report on the delivery of hiv and sexual reproductive health education in school settings in Nauru, Niue, Palau and Samoa. Paris: UNESCO; 2015.

3. United Nations Educational, Scientific, and Cultural Organization. Implementation of sexuality education in middle schools in China. Paris: UNESCO; 2018

4. United Nations. Transforming Our World: The 2030 Agenda for Sustainable Development. A/RES/70/1. UN; 2015. https://sustainabledevelopme nt.un.org/content/documents/21252030\%20Agenda\%20for\%20Sustaina ble\%20Development\%20web.pdf. Accessed 30 July 2020.

5. National AIDS Control Organization. Adolescent Education Programme. Life Skills Development. http://164.100.130.11:8091/webarsh/Resources\% 20on\%20ARSH/Adolescent\%20Education\%20Programme\%20Facilita tors\%20Guide.pdf. Accessed 27 Jul 2020.

6. Balasubramanian P, Prakash RR, Srilakshmi N. Religious fundamentalism and comprehensive sexuality education in South India. Building new constituencies for women's sexual and reproductive health (SRHR) and rights: interlinkages between Religion and SRHR. Karumarapakkam: Rural Women's Social Education Centre; 2016.

7. No sex education in Karnataka schools now: Minister. Onelndia. 2007 April 18. https://www.oneindia.com/2007/04/18/no-sex-education-inkarnataka-schools-now-minister-1176893759.html. Accessed 29 Jul 2020.

8. Tripathi N, Sekher TV. Youth in India ready for sex education? Emerging evidence from National Surveys. PLoS ONE. 2013;8:e71584.

9. Thirunavukarasu A, Simkiss D. Developments in reproductive health education in India. J Trop Pediatr. 2013;59:255-7.

10. Lebese RT, Davhana-Maselesele M, Obi CL. Sexual health dialogue between parents and teenagers: an imperative in the HIV/AIDS era. Curationis. 2010;33:33-42

11. Wilson SF, Strohsnitter W, Baecher-Lind L. Practices and perceptions among pediatricians regarding adolescent contraception with emphasis on intrauterine contraception. J Pediatr Adolesc Gynecol. 2013;26:281-4.

12. Parwej S, Kumar R, Walia I, Aggarwal AK. Reproductive health education intervention trial. Indian J Pediatr. 2005;72:287-91.

13. Ramiro $L$, Reis $M$, de Matos MG. Health and sexuality education in portugal: principal's, teacher's, parent's and student's perception. J Healthc Commun. 2015;1:1-10

14. Mchunu NJ. Teachers' perceptions of the teaching of sexuality education in secondary schools in the Pinetown district [Dissertation]. Pinetown: University of KwaZulu-Natal; 2007.
15. United Nations Educational, Scientific, and Cultural Organization. Levers of Success: Case studies of National Sexuality Education Programmes. Paris: UNESCO; 2010. http://unesdoc.unesco.org/images/0018/001884/ 188495e.pdf. Accessed 25 July 2020

16. Esia-Donkoh K, Kumi-Kyereme A, Awusabo-Asare K, Stillman M. Perceptions about sexuality education in Ghana. 2017. https://iussp.confex.com/ iussp/ipc2017/mediafile/Presentation/Paper2807/Perceptions\%20abo ut\%20sexuality\%20education\%20in\%20Ghana_extended.pdf.Accessed 25 July 2020.

17. Yusran S, Sabilu Y, Yuniar N, Hanafi H, Badara H. The needs of sexual and reproductive health education for secondary school in Kendari City, Southeast Sulawesi, Indonesia. Indian J Sci Technol. 2018;11:1-9.

18. Eisenberg ME, Madsen N, Oliphant JA, Sieving RE. Barriers to providing the sexuality education that teachers believe students need. J Sch Health. 2013;83:335-42.

19. Kibombo R, Neema S, Moore AM, Ahmed FH. Adults' perceptions of adolescents' sexual and reproductive health: qualitative evidence from Uganda, (Occasional Report No. 35). New York: Guttmacher Institute; 2008.

20. Herman L, Ovuga E, Mshilla M, Ojara S, Kimbugwe G, Adrawa AP, Mahuro N. Knowledge, perceptions and acceptability to strengthening adolescents' sexual and reproductive health education amongst secondary schools in Gulu district. World Acad Sci Eng Technol. 2013;7:1787-802.

21. Mohammed M, Sadiq AM, Mohammed K. Perception of parent's and teacher's towards introduction of sex education in senior secondary schools in Bauchi State Nigeria. IOSR JRME. 2018;8:20-5.

22. Fentahun $\mathrm{N}$, Assefa T, Alemseged F, Ambaw F. Parents' perception, students' and teachers' attitude towards school sex education. Ethiop J Health Sci. 2012;22:99-106.

23. Esimai A. Introduction of sex education into Nigerian schools: the Parents', Teachers' and students' perspectives [Dissertation]. Ile-Ife: Obafemi Awolowo University; 2003.

\section{Publisher's Note}

Springer Nature remains neutral with regard to jurisdictional claims in published maps and institutional affiliations.
Ready to submit your research? Choose BMC and benefit from:

- fast, convenient online submission

- thorough peer review by experienced researchers in your field

- rapid publication on acceptance

- support for research data, including large and complex data types

- gold Open Access which fosters wider collaboration and increased citations

- maximum visibility for your research: over 100M website views per year

At BMC, research is always in progress.

Learn more biomedcentral.com/submissions 